\title{
IL16 Gene
}

National Cancer Institute

\section{Source}

National Cancer Institute. IL16 Gene. NCI Thesaurus. Code C28605.

This gene is involved in chemotaxis and is a pro-inflammatory factor. 